\title{
PASUKAN HOME GUARD PERSEKUTUAN TANAH MELAYU SEMASA DARURAT, 1948-1960
}

\author{
Mohd Razali Bin Ya'cob@ Jusoh
}

\begin{abstract}
This article examines the formation of the Home Guard during the Emergency in Malaya. Soon after the Second World War, Malaya faced another serious conflict which was an enternal conflict. The Malayan Communist Party set out to destabilize the country through an around revolt such as attacked the civilians and security forces, destroyed the rubber estate and mining areas, burned the buses, destroyed railways and so forth. The British declared an Emergency to facilitate action againts the Malayan Communist Party. The Home Guard was set up in Malaya to boost local defences which it was made up of local residents from different ethnics such as Malay, Chinese and Indian. They helped to safeguard villages, towns, rubber estates, resettlement areas and new villages from communist's threat. Together with security forces, they also carried out patrol and investigation routines. This article examine the origin of the Home Guard as well as duties, contributions, membership and military exercises of the force and consider it's development during this period.
\end{abstract}

\section{Pengenalan}

Tempoh antara 1948-1960 merupakan suatu tahap yang mencabar fizikal dan minda bagi penduduk di Tanah Melayu ketika itu. Cabaran yang berbentuk ancaman subversif, pembunuhan, penculikan dan kemusnahan harta benda bukan sahaja terpaksa ditanggung oleh pihak kerajaan tetapi juga oleh penduduk awam. Tempoh tersebut dikenali sebagai zaman Darurat apabila Parti Komunis Malaya (PKM) bertindak mencetuskan pemberontakan bersenjata pada 1948 ke arah usaha parti tersebut menubuhkan sebuah Republik Komunis di Tanah Melayu. Keganasan yang telah dicetuskan oleh pengganas komunis telah menyebabkan kerajaan mengisytiharkan Undang-undang Darurat di seluruh Tanah Melayu pada 18 Jun $1948 .^{1}$

Harus dinyatakan bahawa gerakan komunisme sebenarnya bermula lebih awal dari tahun 1948 lagi. Ideologi komunisme di Tanah Melayu berasal dari China dan mula disebarkan pada tahun 1920-an dengan menggunakan cabang Parti Kuomintang China yang telah ditubuhkan di Tanah Melayu pada tahun yang sama. ${ }^{2}$ Pada tahun 1930, PKM telah ditubuhkan di Negeri Sembilan. Dalam usaha PKM untuk menyebarkan 
ideologi komunisme dan mendapatkan pengaruh dalam kalangan rakyat, PKM menggunakan pelbagai kaedah. Antara kaedah tersebut adalah dengan menyerap masuk dalam kesatuan buruh, pertubuhan, sekolah malam, menggunakan pendekatan syarahan, ceramah, penerbitan dan penyebaran risalah yang berunsur komunisme. ${ }^{3}$

Kegagalan gerakan awal tadi dalam mendapatkan pengaruh dan tempat telah menyebabkan PKM mengubah pendekatan mereka. ${ }^{4}$ Mulai 1948, PKM bertindak mengangkat senjata menentang pihak kerajaan dalam usaha menubuhkan sebuah negara republik komunis. Pemberontakan PKM ini menggunakan pelbagai modus operandi. Antaranya, melakukan penculikan ke atas orang awam, menyerang kedudukan anggota pasukan keselamatan, membakar kampung, menyerang kemudahan awam seperti jambatan, landasan kereta api, dan saluran paip air. ${ }^{5}$ Pihak komunis turut bertindak menyerang dan memusnahkan sumber-sumber ekonomi Tanah Melayu ketika itu seperti memotong pokok getah, menyerang kawasan perlombongan bijih timah dan kapal korek dan membakar kilang. ${ }^{6}$

Kesemua tindakan komunis ini telah mengakibatkan pihak kerajaan dan rakyat mengalami banyak kerosakan harta benda dan kehilangan nyawa. Berdasarkan statistik yang diperoleh, sehingga 30 September 1951 sejumlah 1,696 orang awam telah dibunuh. Daripada jumlah ini, sejumlah 1,147 mangsa adalah orang Cina, 251 orang Melayu, 132 orang India, 78 orang Eropah, 60 orang Sakai, 13 orang Indonesia dan selebihnya terdiri daripada orang Siam dan lain-lain. ${ }^{7}$ Sementara itu, sejumlah 390 orang anggota polis dan 489 orang anggota Special Constable dan Auxiliary Police turut terkorban dalam tempoh tersebut. ${ }^{8}$ Bagi keseluruhan tempoh Darurat pula, dari tahun 1948 hingga 1960, sejumlah 5,148 orang telah terbunuh dan didapati hilang. Jumlah ini meliputi 3,283 orang awam dan selebihnya merupakan anggota pasukan keselamatan. ${ }^{9}$

Undang-undang Darurat yang diisytiharkan oleh kerajaan pada 16 Jun 1948 telah membolehkan kerajaan mengambil pelbagai tindakan dalam usaha membanteras habis-habisan akan ancaman yang telah dicetuskan oleh pengganas komunis. ${ }^{10}$ Salah satu tindakan yang dibuat oleh pihak kerajaan adalah dengan menubuhkan pasukan pengawal kampung atau Home Guard di kampung-kampung dan juga Kampung Baru. Tujuannya adalah bagi memastikan kawalan keselamatan di kawasan terbabit dapat dikawal rapi oleh penduduk tempatan sendiri dengan kerjasama pasukan keselamatan yang lain.

\section{Sejarah Penubuhan, Matlamat dan Peranan Pasukan Home Guard}

Selain pasukan Home Guard, telah wujud sebelum itu pasukan-pasukan lain yang seumpamanya di Tanah Melayu ketika itu. Selain polis dan 
tentera (termasuk pasukan dari negara Komanwel), terdapat juga pasukan Special Constabulary (SC), Police Jungle Squad, Police Field Force (PFF) dan Auxiliary Police (AP). Pasukan SC telah ditubuhkan pada 25 Jun 1948 ekoran tindakan komunis yang memusnahkan ladang getah, lombong dan harta benda persendirian. ${ }^{11}$

Pasukan SC berperanan melakukan tugas-tugas kawalan seperti melindungi estet, lombong dan kilang di kawasan luar bandar, menjadi pengiring kepada pengurus estet dan lombong, membuat kawalan di kawasan-kawasan berisiko dan membuat sekatan kawalan makanan. ${ }^{12}$ Police Jungle Squad pula telah ditubuhkan pada lewat 1948 ekoran keperluan membuat operasi memerangi komunis di dalam hutan yang mendesak. Pasukan ini merupakan sebuah pasukan separa tentera. Pasukan ini lebih dikenali sebagai Flying Squad, yang terdiri daripada 15 hingga 20 orang dan diletakkan di bawah kawalan dan arahan Officer Commanding Police District (OCPD). ${ }^{13}$

Pada tahun 1951, sejumlah 200 orang anggota sambilan Jungle Squad telah distruktur semula bagi membentuk 22 Jungle Companies yang selepas itu telah ditukarkan kepada nukleus PFF. ${ }^{14}$ PFF merupakan sebuah pasukan bertaraf operasi sepenuh masa yang ditugaskan untuk membuat operasi membasmi komunis di dalam hutan. Dalam pada itu, serangan komunis yang semakin berleluasa sewaktu awal Darurat telah menyebabkan orang awam tampil secara sukarela untuk menyertai Auxiliary Police. Antara tugas-tugas pasukan AP ialah mempertahankan kampung dan pekan mereka dari serangan komunis, menggantikan tugas-tugas am polis yang diarahkan untuk membuat operasi, mengawal lombong dan melindungi pelombong. ${ }^{15}$

Dalam pada itu, Lt. Gen. Sir Harold Briggs telah dilantik sebagai Pengarah Operasi di Tanah Melayu pada April 1950 bagi membantu pihak kerajaan menghadapi ancaman komunis. ${ }^{16}$ Salah satu langkah yang diambil oleh beliau dalam memerangi ancaman komunis adalah dengan meneruskan rancangan penempatan semula yang telah dilakukan oleh Sir Henry Gurney. ${ }^{17}$ Menurut beliau, "kunci utama bergantung kepada kawalan setinggan-setinggan" dan ini menunjukkan bahawa satu mekanisme perlindungan ke atas penduduk harus diwujudkan khususnya mereka yang berada di luar bandar dan kampung baru. ${ }^{18}$ Tidak dinafikan bahawa kewujudan pasukan-pasukan lain seperti SC dan AP memang bertujuan memberi perlindungan di kawasan kampung dan luar bandar tetapi tidak secara menyeluruh. Tambahan pula, jumlah anggota tentera dan polis yang digunakan untuk mengawal kawasan setinggan ini sedikit sebanyak membataskan usaha mereka untuk membuat operasi pembasmian komunis di tempat-tempat yang berisiko. Oleh itu, perlu diwujudkan suatu pasukan khas dengan anggotanya 
terdiri daripada masyarakat dalam sesebuah kawasan terbabit. Dengan itu, Briggs bertindak menubuhkan pasukan Home Guard dengan tujuan mengawal kawasan-kawasan berisiko yang diserang komunis seperti kampung-kampung, pekan, ladang getah, penempatan semula dan Kampung Baru. Usaha ini telah dimulakan pada lewat tahun 1951 di 280 buah Kampung Baru dan setiap Kampung Baru mempunyai pasukan Home Guardnya yang tersendiri. ${ }^{19}$

Pasukan Home Guard merupakan sebuah pasukan yang anggotanya terdiri daripada rakyat biasa dan mereka ini diletakkan di bawah bidang kuasa Home Guard Regulations 1950 dan Home Guard Regulations 1951.20 Menurut peruntukan ini, dengan kuasa yang diberi kepada Menteri Besar dan Resident Commissioner, mana-mana kawasan yang perlu ditubuhkan sebuah pasukan Home Guard, maka mereka yang berumur antara 18 tahun hingga 55 tahun boleh dikerah untuk menjadi anggota pasukan Home Guard. ${ }^{21}$ Penubuhan pasukan Home Guard tidak terbatas kepada kaumkaum tertentu sahaja sebaliknya pasukan tersebut meliputi seluruh kaum dengan tujuan mereka mampu melindungi kawasan penempatan mereka sendiri, mengambil tindakan segera sekiranya diancam, dan seterusnya membantu pasukan keselamatan yang lain seperti tentera dan polis. ${ }^{22}$

Usaha penubuhan pasukan Home Guard telah digerakkan bermula September $1950 .{ }^{23}$ Pasukan ini telah ditubuhkan di semua peringkat iaitu peringkat negeri, daerah, mukim, dan kampung dan anggota pasukan ini telah diberikan latihan kawad, kemahiran menggunakan senjata, taktik berkawal, bertempur, dan lain-lain lagi. ${ }^{24}$ Sewaktu mereka menjalankan tugas, anggota pasukan Home Guard akan diberikan surat kuasa dan mereka mempunyai tanda pengenalan diri sebagai ahli Home Guard iaitu merupakan kain yang bertanda " $\mathrm{HG}$ " yang dililit di lengan kiri baju. ${ }^{25}$ Pada awal penubuhannya, terdapat juga ahli Home Guard yang hanya bersenjatakan parang ketika membuat rondaan kerana penggunaan senjata adalah terhad, sebaliknya penggunaan senjata lebih diutamakan kepada pasukan polis dan tentera. Namun demikian, dengan ancaman pihak komunis yang semakin berleluasa sewaktu awal 1950-an, maka senjata mula ditambah jumlahnya untuk kegunaan pasukan Home Guard. ${ }^{26}$

Terdapat beberapa matlamat yang ingin dicapai oleh pihak kerajaan dalam menubuhkan pasukan Home Guard ini. Pertama, adalah untuk memastikan bahawa masyarakat, terutamanya di luar bandar merasai tanggungjawab dalam melindungi penempatan mereka iaitu dengan menubuhkan sebuah pasukan Home Guard yang terdiri dari pelbagai kaum. ${ }^{27}$ Bagi pihak kerajaan, untuk menentang pemberontakan yang dicetuskan oleh pihak komunis dan penyebaran dakyah komunis, rakyat perlu dilibatkan sekali kerana rakyat merupakan elemen yang penting. 
Sekiranya rakyat tidak dilindungi, maka dengan mudah mereka akan terpengaruh dengan komunisme dan seterusnya menyokong perjuangan PKM. Perkara inilah yang disedari oleh Briggs apabila beliau datang ke Tanah Melayu dan mengetuai gerakan menentang PKM. Bagi beliau, untuk membendung dan menghapuskan pihak komunis tidak boleh hanya menggunakan pendekatan ketenteraan semata-mata, sebaliknya usaha yang melibatkan rakyat juga perlu dilakukan. Antara usaha tersebut ialah menubuhkan sebuah pasukan yang anggotanya terdiri daripada penduduk di sesebuah tempat.

Kedua, matlamat penubuhan Home Guard adalah bagi memastikan pihak komunis dapat dihapuskan sepenuhnya di samping mereka boleh membantu pihak keselamatan lain membuat rondaan dan serangan hendap terhadap kedudukan musuh. ${ }^{28}$ Walaupun pasukan keselamatan lain seperti polis dan tentera turut ditambah keanggotaan dan persenjataannya, namun adalah tidak praktikal bagi pasukan-pasukan tersebut untuk membuat kawalan secara tetap selama 24 jam di kawasankawasan kampung, Kampung Baru, pekan kecil, dan juga ladang getah. ${ }^{29}$ Hal ini demikian kerana pihak komunis bukan sahaja bertumpu di kawasan bandar, lombong, estet, sebaliknya mereka juga bergiat aktif di dalam hutan. Sekiranya pasukan polis dan tentera dikerahkan untuk memerangi mereka dalam satu-satu masa, sudah pasti bagi sesetengah kawasan, kawalan keselamatannya akan menjadi longgar dan ini akan memberi ruang untuk pihak komunis bertindak. Dengan wujudnya pasukan Home Guard ini, tugas-tugas kawalan dapat dijalankan oleh mereka sendiri manakala pasukan polis dan tentera boleh digerakkan bagi tujuan pertahanan dalam membendung ancaman pihak komunis. ${ }^{30}$

Matlamat yang ketiga pula ialah untuk membendung penyebaran ideologi komunis dalam kalangan rakyat. ${ }^{31}$ Pihak kerajaan melihat jauh ke hadapan sekiranya usaha PKM untuk menubuhkan sebuah negara yang berasaskan komunis gagal dengan menggunakan pendekatan perang gerila. PKM dilihat berkemungkinan menukar taktiknya daripada bercorak gerila kepada gerakan subversif di mana PKM akan menggunakan cabang dari PKM iaitu Min Yuen. ${ }^{32}$ Min Yuen merupakan sebuah pasukan yang menjalankan kerja-kerja subversif seperti menyerap masuk ke dalam beberapa pertubuhan seperti pertubuhan belia, kesatuan sekerja serta mempengaruhi dan melatih individu-individu tertentu supaya terpengaruh dengan ideologi komunis seterusnya menyertai PKM. Bagi menghadapi kemungkinan tersebut, maka pasukan Home Guard perlu ditubuhkan bagi memastikan gerakan subversif yang cuba dilakukan oleh Min Yuen terutamanya di kawasan luar bandar dapat ditangani dengan segera. ${ }^{33}$ 
Walaupun anggota Home Guard kebanyakannya terdiri daripada rakyat biasa, namun peranan dan tanggungjawab yang diberikan bukanlah mudah dan tidak boleh dipandang ringan. Pasukan ini ditugaskan untuk melindungi penempatan mereka di samping mengambil tindakan segera apabila diancam oleh pihak komunis termasuklah kawasan atau tempat mereka bekerja., ${ }^{34}$ Penempatan yang dimaksudkan adalah merujuk kepada kawasan kampung, Kampung Baru, ladang dan estet. Mereka akan membuat rondaan mengikut kawasan yang telah ditetapkan atau diarahkan oleh pasukan polis. ${ }^{35}$ Mereka juga diminta untuk mengawal beberapa kawasan strategik yang lain seperti tempat simpanan senjata api, kawasan perlombongan dan estet. ${ }^{36}$

Bagi kawasan kampung lama yang mempunyai jumlah keluarga yang kurang daripada 30 buah rumah, pasukan Home Guard yang ditugaskan mengawal kampung khususnya pada waktu malam adalah terdiri daripada penduduk kampung itu sendiri. Mereka dikehendaki untuk bertugas secara berkumpulan tidak melebihi sepuluh orang pada setiap malam. ${ }^{37}$ Manakala bagi kampung yang lebih besar jumlah penduduknya, seramai 15 orang atau lebih akan ditugaskan untuk berkawal setiap pada malam dan setiap tiga orang daripada mereka akan diberikan selaras senapang. ${ }^{38}$

Bagi kawasan Kampung Baru pula, keanggotaan pasukan Home Guard adalah sepenuh masa. Mereka dikehendaki membantu pasukan keselamatan, polis, dan Special Constable (SC) memeriksa kad pengenalan dan bekalan makanan yang dibawa oleh penduduk kampung yang keluar masuk ke kawasan tersebut. ${ }^{39}$ Pada peringkat awal bertugas, pasukan Home Guard tidak dibekalkan dengan senjata sebaliknya mereka hanya ditugaskan mengawal kawasan berpagar dengan kawat berduri. ${ }^{40}$ Mereka hanya dibekalkan dengan senjata api setelah mereka benar-benar didapati jujur dan boleh dipercayai. ${ }^{41}$ Kepercayaan ini penting kerana wujudnya kes di mana senjata yang dibekalkan kepada pasukan Home Guard telah berjaya sampai ke tangan pengganas komunis. Misalnya pada 29 Ogos 1951, tujuh orang pengganas komunis Cina bertindak merampas tiga laras senapang dan 52 butir peluru daripada lima orang anggota Home Guard Melayu di Daerah Kuala Krai dan pada 27 September 1951, pengganas bertindak merampas 11 laras senapang dan 231 butir peluru dari anggota Home Guard di kawasan Manek Urai. ${ }^{42}$ Di Johor, pada 29 September 1951, pengganas komunis bertindak mengepung pos kawalan Home Guard di Tongkong Pechah, Daerah Batu Pahat dan berjaya merampas lima laras senapang dan 95 butir peluru. ${ }^{43}$

Di samping itu, pasukan Home Guard juga hendaklah memastikan pihak komunis tidak mendapat sebarang bekalan makanan dan bantuan dari kawasan-kawasan yang dikawal di samping membuatkan sesebuah 
kawasan itu sukar untuk dimasuki oleh pihak komunis. ${ }^{44}$ Mereka juga diarahkan untuk memberikan perhatian kepada orang asing khususnya mereka yang disyaki mempunyai kaitan dengan komunis yang hadir di kampung atau ke kawasan mereka dan kemudian melaporkannya kepada pihak polis..5 Bagi memastikan objektif tersebut dapat dicapai, pasukan Home Guard akan membantu pasukan polis membuat sekatan jalan raya dan memeriksa kad pengenalan penduduk serta menjalankan operasi penapisan di tempat-tempat awam di seluruh negara. ${ }^{46}$ Dalam pada itu, pasukan Home Guard turut diminta untuk mengatur perkhidmatan di sekolah-sekolah dan membuat kerja-kerja kebajikan. ${ }^{47}$

\section{Keanggotaan dan Latihan Pasukan Home Guard}

Pasukan Home Guard boleh dibahagikan kepada dua unit iaitu Static Home Guard dan Operational Home Guard. Anggota yang terdiri daripada Static Home Guard terdiri daripada tiga anggota bagi setiap kumpulan dan salah seorangnya akan diberikan senjata api manakala bagi anggota yang merupakan Operational Home Guard, ia terdiri daripada unit-unit tertentu dan setiap unit terdiri daripada 9 orang. ${ }^{48}$

Pasukan Static Home Guard ini merujuk kepada anggota-anggota yang ditugaskan untuk membuat kawalan dan rondaan keselamatan di kawasan kampung-kampung, Kampung Baru, ladang, dan estet. Dalam membuat kawalan ini, mereka diberikan beberapa tahap operasi yang tertentu. Peringkat pertama, anggota Home Guard yang berkawal merupakan mereka yang sedang dilatih dengan bantuan pihak polis dan tentera dan pihak polis bertanggungjawab sepenuhnya dalam soal keselamatan sesebuah kawasan yang dijaga. ${ }^{49}$ Pada peringkat kedua pula, kawalan keselamatan yang dilakukan akan disertai oleh anggota Home Guard yang telah melengkapkan latihan mereka. Mereka berkongsi tanggungjawab yang sama dalam soal keselamatan kawasan mereka bersama pihak polis dan tentera. ${ }^{50}$ Pada peringkat ketiga pula, kawalan keselamatan sesebuah kawasan sudah mula diambilalih oleh anggota Home Guard yang sudah pun mahir dan mampu berdikari dalam menjalankan tugas. Pada peringkat ini pihak polis dan tentera yang berkawal sebelum ini akan digerakkan ke tempat-tempat lain. Kehadiran mereka lebih diperlukan dalam usaha menentang ancaman komunis. ${ }^{51}$

Bagi pasukan Operational Home Guard pula, pasukan ini berbeza jika dibandingkan dengan pasukan Static Home Guard. Hal ini demikian kerana keanggotaan pasukan ini dipilih berdasarkan kecekapan dan rekod baik yang ditunjukkan oleh mereka sewaktu menjalankan latihan dan mereka dipilih dari kalangan pasukan Home Guard yang telah diwujudkan di kampung-kampung. ${ }^{52}$ Latihan yang diberikan kepada pasukan ini lebih kepada ala tentera yang lebih intensif di kampung-kampung dan 
kawasan-kawasan yang mempunyai banyak gerakan komunis. ${ }^{53} \mathrm{Hal}$ ini sesuai dengan peranan yang dimainkan oleh pasukan ini iaitu membantu pasukan keselamatan seperti polis dan tentera melancarkan operasi serang hendap atau memburu komunis-komunis di dalam hutan. ${ }^{54}$

Bagi memastikan pasukan Home Guard mampu menghadapi ancaman komunis, pasukan ini turut diberikan latihan yang tertentu seakan-akan latihan yang diberikan kepada pasukan keselamatan yang lain. Latihan bagi pasukan ini akan dikendalikan oleh pegawai-pegawai Home Guard sendiri di samping dipantau oleh pegawai polis. Dalam melaksanakan latihan ini, terdapat beberapa prinsip yang cuba dibentuk dan diserapkan dalam kalangan anggota Home Guard. Pertama ialah kesetiaan. Seseorang anggota Home Guard bukan sahaja perlu setia dalam mempertahankan kampung mereka dari ancaman komunis, mereka juga perlu setia sesama ahli pasukan, sama ada dalam situasi aman atau diserang musuh. ${ }^{55}$ Kedua ialah disiplin. Seseorang anggota Home Guard mesti mempunyai tahap disiplin yang tinggi setiap masa bagi memastikan mereka boleh bekerja dengan baik dalam satu pasukan. ${ }^{56}$ Ketiga ialah sentiasa berwaspada. Seseorang anggota Home Guard mesti sentiasa berwaspada terhadap sebarang serang hendap kerana komunis sememangnya mahir dalam membuat serang hendap dan kealpaan seseorang anggota Home Guard akan menyebabkan nyawa dirinya dan pasukan terancam. ${ }^{57}$ Keempat ialah mahir menggunakan senjata. Seseorang anggota Home Guard mesti mahir menggunakan senjata kerana adalah rugi sekiranya mereka bertembung dengan pengganas tetapi tidak dapat membunuh mereka disebabkan tidak mahir menggunakan senjata yang dibekalkan pihak kerajaan. ${ }^{58}$ Kelima ialah mahir dengan keadaan sekeliling. Seseorang anggota Home Guard mesti mahir dengan keadaan sekeliling sekiranya mahu menangani ancaman komunis. ${ }^{59}$

Antara bentuk latihan yang diberikan kepada pasukan ini ialah latihan menggunakan senjata dan menembak, latihan bercorak situasi ketika diserang komunis dan latihan membuat serangan ke atas kedudukan komunis. ${ }^{60}$ Bagi memastikan kemahiran yang dimiliki oleh seseorang anggota Home Guard itu mantap, pertandingan sesama anggota, pasukan atau unit turut diadakan. Pertandingan ini biasanya diatur oleh setiap pasukan Home Guard bagi setiap negeri. Sebagai contoh, pasukan Home Guard Kelantan mengadakan pertandingan menembak meliputi anggota Home Guard, pegawai dan juga mereka yang berminat dan pertandingan yang dibuat adalah seperti jungle contact, carbine competition, falling plate, pump gun competition, dan combined weapon competition. ${ }^{61}$ 


\section{Pentadbiran dan Bidang Kuasa Pasukan Home Guard}

Sewaktu Darurat iaitu pada April 1950, Briggs telah mengarahkan supaya diwujudkan sebuah Majlis Perang Persekutuan (Federal War Council/ FWC) yang berfungsi merangka dasar serta memperuntukkan sumber bagi mengatasi perang melawan komunis. ${ }^{62}$ Di peringkat negeri, ditubuhkan pula Jawatankuasa Kerja Perang Negeri (State War Executive Committee/SWEC). Jawatankuasa ini memainkan peranan untuk memutuskan hubungan antara komunis di hutan dengan penyokongnya di bandar dan kampung serta membuat penyusunan bagi merancang dan menempatkan semula penduduk setinggan di kawasannya. ${ }^{63}$

Di peringkat daerah pula telah ditubuhkan Jawatankuasa Kerja Perang Daerah (District War Executive Committee/DWEC). Peranan yang dimainkan ialah membincangkan dan mencari penyelesaian ke atas perkara-perkara yang melibatkan kawalan makanan, penempatan semula, pengumpulan semula, pengenaan dan pengurangan batasan perintah berkurung, masalah yang ditimbulkan oleh kaum buruh dan perkara lain yang berkaitan dengan perang menentang komunis. ${ }^{64}$ Bagi peringkat SWEC dan DWEC, jawatan bagi Home Guard Officer disertakan sekali bagi tujuan mentadbir dan melatih pasukan Home Guard itu sendiri. ${ }^{65}$

Dalam pasukan Home Guard, jawatan yang tertinggi sekali diketuai oleh State Home Guard Officer, diikuti dengan District Officer, District Home Guard Officer, Battalion Commander, Company Commander, Platoon Commander, dan akhir sekali Section Commander. ${ }^{66}$ Di bawah jawatan State Home Guard Officer, terdapat satu jawatan lagi yang akan membantu beliau iaitu Assistant State Home Guard Officer. ${ }^{67}$ Di bawah jawatan Battalion Commander pula, terdapat dua jawatan yang akan membantu tugas beliau iaitu Home Guard Inspector dan Permanent Staff Instructor. ${ }^{68}$ State Home Guard Officer berfungsi mentadbir pasukan Home Guard yang diwujudkan bagi setiap negeri di mana segala perkara yang melibatkan pentadbiran dan latihan adalah di bawah tanggungjawab beliau ${ }^{69}$ Bagi memudahkan tugas beliau, beliau akan dibantu oleh permanent staff yang meliputi semua peringkat iaitu kampung, Kampung Baru, dan juga estet. ${ }^{70}$ Permanent Staff ini terdiri daripada jawatan Asssistant State Home Guard Officer, District Home Guard Officer, dan juga Home Guard Inspector. ${ }^{71}$ 
Jawatankuasa Kerja Perang Bagi Peringkat Negeri dan Daerah ${ }^{72}$

\begin{tabular}{|c|c|c|}
\hline SWEC & DWEC & Responsible for: \\
\hline \multicolumn{3}{|c|}{ Civil } \\
\hline State Prime Minister & District Officer & Local government \\
\hline Executive Secretary & & $\begin{array}{l}\text { Administraition of Prime } \\
\text { Minister's office }\end{array}$ \\
\hline Information Officer & Information Officer & $\begin{array}{l}\text { Public relations and psychological } \\
\text { Warfare }\end{array}$ \\
\hline \multicolumn{3}{|c|}{ Police } \\
\hline Chief Police Officer & Police Commander & All police in district \\
\hline Head, Special Branch & Special Branch Officer & Police intelligence \\
\hline $\begin{array}{l}\text { Military Intelligence } \\
\text { Officer }\end{array}$ & $\begin{array}{l}\text { Military Intelligence } \\
\text { Officer }\end{array}$ & Assisting Special Branch \\
\hline Home Guard Officer & Home Guard Officer & $\begin{array}{l}\text { Training and administration of } \\
\text { Home Guard }\end{array}$ \\
\hline \multicolumn{3}{|c|}{ Military } \\
\hline Brigade Commander & Battalion Commander & $\begin{array}{l}\text { All troops in district and request } \\
\text { for air support }\end{array}$ \\
\hline
\end{tabular}

Dari segi bidang kuasa pula, pasukan Home Guard sebenarnya diletakkan di bawah kawalan dan arahan pihak polis terutamanya jika mereka terlibat dengan sebarang operasi tetapi dari segi pentadbirannya, pasukan Home Guard diletakkan di bawah pentadbiran Pegawai Daerah sesuai dengan peranannya sebagai Pegawai Pertahanan Awam. ${ }^{73}$ Bagi Home Guard Officer pula, peranan yang dimainkan adalah merekrut anggota Home Guard baru, mengendalikan latihan, membantu tugas pentadbiran, dan menghadiri War Executive Committee (WEC) sebagai penasihat sahaja. ${ }^{74}$

Walaupun pasukan Home Guard diletakkan di bawah bidang kuasa polis, namun seseorang anggota Home Guard diberikan kuasa-kuasa tertentu. Antaranya, seseorang anggota Home Guard diberikan kuasa untuk memasuki sesebuah kediaman dengan tujuan untuk membuat pemeriksaan bagi memastikan jumlah mereka yang tinggal di dalam kediaman tersebut. Selain itu mereka juga diberi kuasa untuk memeriksa dan meminta dokumen yang disimpan atau dokumen yang dikeluarkan oleh penghuni sesebuah kediaman serta mendapatkan maklumatmaklumat yang mungkin diketahui oleh seseorang penghuni. Mereka juga turut berkuasa untuk menahan sesiapa sahaja yang tidak mematuhi Undang-undang Darurat dan membawanya ke balai polis atau pegawai polis. ${ }^{75}$ Di samping itu, seseorang anggota Home Guard juga diberikan kuasa untuk mengambil tindakan ke atas sesiapa yang cuba melengah- 
lengahkan atau mengganggu tugas anggota Home Guard dalam menguatkuasakan sebarang peraturan. ${ }^{76}$

Bagi jawatan pentadbiran dan pengurusan kanan, jawatan tersebut telah dikendalikan oleh pegawai-pegawai tinggi British di mana jawatan bagi Inspector General dan pegawai kanan atau Full Time Home Guard Professsional Staff yang bekerja sepenuh masa merupakan pegawai tetap berbangsa Inggeris. ${ }^{77}$ Mereka juga merupakan penggubal polisi bagi pasukan Home Guard. ${ }^{78}$ Namun demikian, setelah rancangan Malayanization Scheme diperkenalkan pada tahun 1955, jawatan-jawatan kanan dalam pasukan Home Guard telah diberikan kepada penduduk tempatan sedikit demi sedikit. ${ }^{79}$

\section{Perkembangan Pasukan Home Guard Pada Zaman Darurat}

Pada penghujung tahun 1950, terdapat sejumlah 30,000 orang anggota Home Guard di Tanah Melayu. Daripada jumlah tersebut sebanyak 25,400 adalah orang Melayu, 3,500 orang Cina, 800 orang India, dan 300 orang bagi lain-lain kaum..$^{80}$ Bagi menggalakkan lagi orang awam melibatkan diri secara sukarela dalam usaha menentang komunis, Sir Henry Gurney, ${ }^{81}$ Pesuruhjaya Tinggi British di Tanah Melayu telah mengadakan "Kempen Bulan Rakyat Melawan Pengganas". Kempen yang diwujudkan ini adalah untuk memberikan galakan kepada rakyat supaya menyertai pasukan Home Guard. ${ }^{82}$ Kesan daripada kewujudan kempen didapati telah membawa sambutan daripada rakyat ekoran keganasan yang telah dicetuskan oleh komunis seperti tragedi pembakaran Pekan Simpang Tiga di Setiawan, Perak pada 4 Februari 1950 yang menyebabkan kira-kira 1000 orang kehilangan tempat tinggal dan tragedi serangan komunis ke atas Balai Polis Bukit Kepong di Muar, Johor pada 23 Februari 1950 yang mengakibatkan sebahagian besar anggota polis dan polis tambahan terkorban. ${ }^{83}$

Pada bulan Disember 1951, proses penyusunan semula pasukan Home Guard telah dilakukan dan diletakkan di bawah Kementerian Pertahanan. ${ }^{84}$ Pesara tentera British, General E.B. de Fonblanque telah ditugaskan untuk melatih sebanyak 42,000 anggota baru dengan bantuan pegawai-pegawai Komanwel. ${ }^{85}$ Hasil daripada proses tersebut, jumlah anggota pasukan Home Guard didapati telah meningkat iaitu sebanyak 79,000 orang anggota pada bulan Julai 1951 dan 99,000 orang pada akhir tahun tersebut. Bilangan ini pernah mencapai pertambahan sebanyak 250,000 orang pada bulan Jun $1953 .{ }^{86}$ Anggota-anggota yang dilatih bertanggungjawab sepenuhnya ke atas 72 buah Kampung Baru yang diwujudkan ketika itu. ${ }^{87}$

Bagi menambahkan lagi penglibatan orang Cina dalam pasukan Home Guard khususnya bagi menjaga kawasan Kampung Baru, 
penglibatan parti politik digunakan bagi memujuk, menggesa, dan menarik minat orang Cina bagi menyertai pasukan tersebut. Untuk tujuan itu, Malayan Chinese Association (MCA) telah menggerakkan jentera publisiti dan propagandanya ke seluruh Persekutuan Tanah Melayu bagi menyeru orang Cina supaya mendaftarkan diri menyertai pasukan Home Guard. ${ }^{88}$ Tindakan yang dibuat oleh MCA ini mendatangkan hasil menjelang pertengahan tahun 1953. Didapati jumlah orang Cina yang menyertai pasukan Home Guard adalah sebanyak 79,587 orang daripada jumlah keseluruhan anggota Home Guard Persekutuan iaitu kira-kira 244,645 orang. ${ }^{89}$ Pada September 1954, 129 daripada 323 buah Kampung Baru telah diletakkan di bawah kawalan pasukan Home Guard Cina. ${ }^{90}$

Pada penghujung tahun 1957, beberapa buah negeri seperti Seberang Perai, Terengganu dan beberapa buah negeri yang lain didapati telah bebas daripada ancaman komunis. ${ }^{91}$ Dengan ancaman komunis yang semakin berkurangan, maka suatu langkah telah diambil bagi mengurangkan jumlah pasukan Home Guard yang sedia ada secara perlahan-lahan dan meninggalkan sebilangan kecil sahaja untuk dijadikan rangka-rangka bagi mendirikan pasukan itu sekiranya perlu. ${ }^{92}$ Menjelang 1958, jumlah keseluruhan anggota pasukan Home Guard di Tanah Melayu ialah berjumlah 68,000 orang. Anggota-anggota adalah terdiri daripada platun-platun tindakan (Operational Platoons) tugas am, pasukan-pasukan tindakan (Operational Sections) di kampung-kampung, pasukan-pasukan "kawasan putih" di negeri-negeri yang belum bebas daripada ancaman komunis dan pasukan Home Guard Lembah Kinta. ${ }^{93}$

Dengan ancaman dari PKM yang semakin berkurangan dan dapat dikawal, secara tidak langsung keanggotaan dalam pasukan Home Guard turut dikecilkan sedikit demi sedikit berdasarkan keadaan semasa di akhir 1960-an. Pada 25 Ogos 1959, Majlis Gerakan Darurat telah membuat keputusan untuk mengurangkan jumlah pasukan Home Guard di Tanah Melayu bermula 1959. ${ }^{94}$ Antara perkara yang dipersetujui ialah bermula 1 Januari 1959, pasukan Home Guard di Kelantan dan Terengganu akan dibubarkan manakala pasukan Home Guard di Selangor, Pahang, Negeri Sembilan akan distruktur semula berdasarkan kewujudan Kawasan Putih yang semakin berkembang. ${ }^{95}$ Bagi pasukan Home Guard di Johor dan Perak pula, jumlah pasukan yang ada akan dikurangkan masing-masing sebanyak $2 / 3$ dan $1 / 3$ dalam kadar segera di mana pasukan yang diwujudkan adalah bersaiz kecil bergantung kepada Kawasan Putih yang diisytiharkan. ${ }^{96}$

Keputusan lain yang turut dicapai dalam mesyuarat tersebut ialah pasukan Home Guard di Selangor dan Pahang akan dibubarkan pada 1 April 1959. ${ }^{97}$ Manakala bermula 1 Julai 1959, pasukan Home Guard di Melaka, Negeri Sembilan, Johor pula akan dibubarkan. ${ }^{98}$ Bagi pasukan 
Home Guard di Perak pula, jumlah pasukan Home Guard yang ada akan dikurangkan jika keadaan keselamatan berjaya dikawal terutamanya di sekitar kawasan tengah Perak yang sering kali diancam komunis. ${ }^{99}$ Bagi pasukan Home Guard di Kedah, Perlis dan Pulau Pinang, jumlah pasukan yang sedia ada dikekalkan buat sementara waktu sehingga keadaan keselamatan di kawasan putih benar-benar bebas dari ancaman komunis. Setelah dirasakan tiada lagi keperluan untuk mengekalkan pasukan ini, maka secara rasminya pasukan Home Guard di Tanah Melayu mula dibubarkan pada 1 Julai $1959 .{ }^{100}$

\section{Sumbangan Pasukan Home Guard Semasa Darurat 1948-1960}

Secara umumnya, sejak pasukan Home Guard ditubuhkan sehingga tahun 1958, pasukan ini telah berjaya membunuh seramai 221 orang pengganas komunis. Mereka telah berjaya menawan seramai 23 orang dan mencederakan seramai 110 orang pengganas. Manakala seramai 123 orang pengganas telah menyerah diri kepada pasukan Home Guard. ${ }^{101}$

Sumbangan pasukan Home Guard ini boleh dilihat berdasarkan peranan yang telah dimainkan oleh pasukan ini. Dengan kawalan yang lebih kerap dilakukan ke atas kawasan kampung, Kampung Baru, dan estet telah menyebabkan serangan pengganas komunis dapat dikurangkan. Selain itu, dengan wujudnya kawalan keselamatan di bawah pasukan Home Guard, ia telah memberikan kesukaran bagi pengganas komunis untuk menyusup masuk ke Kampung-kampung Baru bagi mendapatkan bekalan makanan, ubatan, dan juga pakaian di samping maklumat berkaitan dengan gerakan pasukan keselamatan. Sebagai contoh, pada tahun 1952 kawasan Tanjung Malim didapati sering kali diancam oleh pengganas komunis. Komunis-komunis tersebut telah bertindak membunuh 15 orang penduduk kampung, menyerang landasan kereta api sebanyak dua kali, membuat serangan hendap di jalan raya sebanyak 10 kali, membakar lapan buah trak dan bas, serta memusnahkan 6000 pokok getah. ${ }^{102}$ Keganasan yang dicetuskan oleh pengganas komunis ini telah menyebabkan penduduk kampung menubuhkan pasukan Home Guard dan seramai 3,500 orang telah menyertainya. ${ }^{103}$ Dengan penubuhan pasukan ini, pengganas komunis yang sebelum itu telah banyak membuat serangan mula berpecah dan keluar dari kawasan Tanjung Malim dan selama lapan tahun seterusnya kawasan Tanjung Malim tidak lagi menghadapi sebarang ancaman komunis. ${ }^{104}$

Pasukan Home Guard Kelantan sewaktu dalam proses pembangunannya telah berjaya membunuh tiga orang pengganas komunis dan merampas sepucuk stengun, dua rifle dan bom tangan. Sejumlah besar bekalan peluru telah ditemui di kawasan Bertam di 
samping tiga peluru stengun, bekalan perubatan serta peralatan. ${ }^{105}$ Kejayaan yang dicapai oleh pasukan Home Guard Kelantan ini mendapat reaksi yang menggembirakan daripada Pesuruhjaya Tinggi British, Sir Gerald Templer. ${ }^{106}$

Di samping itu, pasukan Home Guard telah mula meluaskan peranannya daripada berkawal dan meronda semata-mata kepada tindakan yang lebih drastik dalam usaha pihak kerajaan menghapuskan komunis. Sepanjang tahun 1953 dan 1954, pengganas komunis terus menerima serangan hebat di kawasan-kawasan persembunyian mereka, terutama sekali dengan pelancaran operasi besar-besaran yang dilakukan oleh pihak polis dan Home Guard di Kelantan, timur Pahang, dan barat Perak. ${ }^{107}$

Sumbangan pasukan Home Guard juga boleh dilihat dari segi keberanian anggotanya ketika menjalankan tugas. Sebagai contoh, pada 22 November 1952 bertempat di Kampung Jelai, Perak, lima orang anggota Home Guard yang terdiri daripada Mat Nor Abdul Wahid, Mohd Yin bin Sidek, Mohamed bin Haroun, Rajudin bin Mat Rudin, dan Hashim bin Sidek terlibat dalam satu serang hendap di kampung tersebut. Dalam serang hendap tersebut, mereka berjaya membunuh seorang anggota komunis Cina yang dikenali sebagai Ah Wan, berbangsa Hainan yang merupakan pembantu peribadi kepada salah seorang pemimpin komunis di kawasan tersebut. Beliau begitu diperlukan sehingga ditawarkan ganjaran kepada sesiapa yang berjaya menangkapnya dengan ganjaran besar sebanyak $\$ 35,000 .{ }^{108}$

\section{Kesimpulan}

Secara kesimpulan, dapat dinyatakan bahawa semasa zaman Darurat, selain pasukan polis, tentera, Jungle Squad dan Special Constabel, pasukan Home Guard turut ditubuhkan dalam membantu usaha kerajaan menentang ancaman komunis. Pembentukan pasukan ini yang terdiri daripada orang awam juga membuktikan bahawa usaha melawan komunis bukan sahaja dilakukan oleh pihak kerajaan semata-mata sebaliknya turut dilakukan oleh rakyat yang kebanyakannya menyertai pasukan Home Guard. Di samping itu juga, dapat dilihat bahawa pasukan Home Guard mempunyai sistem pentadbiran dan latihan yang sistematik sepertimana yang diamalkan oleh pasukan-pasukan keselamatan lain. Melaluinya, pasukan ini berjaya dibentuk dengan baik dan mencapai kejayaan dalam operasi-operasi yang dilakukan ketika zaman Darurat. 


\section{Nota}

1 Pengisytiharan Darurat sebenarnya telah dibuat lebih awal oleh Sir Edward Gent yang merupakan Pesuruhjaya Tinggi British ketika itu. Keganasan komunis mencapai kemuncaknya apabila 3 orang peladang Eropah telah mati dibunuh di Sungai Siput, Perak pada 16 Jun 1948. Kejadian tersebut menyebabkan Darurat diisytiharkan pada petang tersebut meliputi kawasan Ipoh dan Sungai Siput, Perak serta daerah Kluang, Muar, Kulai dan Plentong di Johor. Butiran lanjut, sila rujuk Ho Hui Ling, Darurat 1948-1960 Keadaan Sosial di Tanah Melayu, Kuala Lumpur: Penerbit Universiti Malaya, 2004, hlm. 15. Rujuk juga Raj, J.J. Jr., The Struggle For Malaysian Independence, Petaling Jaya: MPH Group Publishing Sdn. Bhd., 2007, hlm. 80-81; Mohd. Reduan Haji Asli, Pemberontakan Bersenjata Komunis Di Malaysia Edisi Kedua, Kuala Lumpur: Dewan Bahasa dan Pustaka, 2008, hlm. 28-29; Abdullah Zakaria Ghazali, Ho Hui Ling \& Mahmud Embong, Darurat Di Kelantan 1948-1960 Pengalaman dan Iktibar, Kota Bharu: Perbadanan Muzium Negeri Kelantan, 2009, hlm. 17; Hassan Yusoff, 'Pasukan Polis Di Tanah Melayu Semasa Bermula Kempen Keganasan Komunis Sehingga Pengisytiharan Undangundang Darurat: 1947-Ogos 1948', dalam Malaysia dari segi Sejarah, Bil. 25, Kuala Lumpur: Persatuan Sejarah Malaysia, 1997, hlm. 17.

2 Pada ketika itu, Kuomintang wujud sebagai sebuah parti politik yang sah di Persekutuan Tanah Melayu sehinggalah bulan Julai, 1923. Rujuk Wan Hamzah Awang, Detik Sejarah Rundingan Baling, Kuala Lumpur: Utusan Publications \& Distributors Sdn. Bhd., 1985, hlm. 4. Maklumat lanjut mengenai Kuomintang, rujuk juga Abdullah Zakaria Ghazali, Ho Hui Ling \& Mahmud Embong, Darurat Di Kelantan 1948-1960, hlm. 3.

${ }^{3}$ Sebagai contoh, pada Mac 1923, di Selangor telah ditubuhkan sebuah sekolah malam yang dinamakan Phing Man. Sekolah ini telah digunakan untuk menyebarkan dakyah kebangsaan Cina serta komunis. Malah, kertas, buku harian dan surat-surat yang dirampas oleh pemerintah pada Disember 1923 menunjukkan bahawa salah seorang guru di sekolah itu, Han Kuo Hsiang pernah mendapat latihan di negeri Rusia. Pertubuhan-pertubuhan buruh Komunis pula telah pun muncul pada tahun 1926. Misalnya, pada Mei 1926, Kesatuan Buruh Am Nanyang telah diasaskan di Singapura dan mempunyai cawangan di seluruh Tanah Melayu, Hindia Timur Belanda, Siam dan Sarawak. Di Negeri Sembilan juga terdapat lebih kurang sepuluh persatuan yang cenderung kepada komunis pada tahun 1926. Untuk rujukan lanjut, sila rujuk Khoo Kay Kim, "Gerakan Komunis di Tanah Melayu Sehingga Tertubuhnya PKM", dalam Khoo Kay Kim dan Adnan Nawang (eds.), Darurat 1948-1960, Kuala Lumpur: Muzium Angkatan Tentera, 1984, hlm. 22, 23 dan 24; Wan Hamzah Awang, Detik Sejarah Rundingan Baling, hlm. 5.

${ }^{4}$ Kegagalan yang dimaksudkan ialah perjuangan PKM untuk mewujudkan sebuah negara komunis gagal apabila Persekutuan Tanah Melayu telah dibentuk pada 1 Februrari 1948.

${ }^{5}$ Sepanjang zaman Darurat 1948-1960, perkhidmatan Keretapi Tanah Melayu mengalami 197 kejadian kegelinciran, 171 kali ditembak oleh pengganas, 18 stesen musnah, 580 alat perhubungan dan semboyan rosak, 441 kejadian sabotaj landasan dan jambatan, serta 78 lokomotif musnah. Rujuk Hassan Yusoff, 
'Pasukan Polis Di Tanah Melayu Semasa Bermula Kempen Keganasan Komunis Sehingga Pengisytiharan Undang-undang Darurat: 1947-Ogos 1948', dalam Malaysia dari segi Sejarah, hlm. 15.

6 Tahap awal Darurat di Tanah Melayu, dikatakan purata serangan yang dilakukan oleh pihak komunis ke atas orang awam dan pasukan keselamatan adalah lebih kurang 200 serangan dalam tempoh sebulan. Rujuk Raj (JR), J.J., The Struggle For Malaysian Independence, hlm. 115.

7 Handbook to Malaya (Federation of Malaya \& the Colony of Singapore) And The Emergency, Singapore: The Regional Information Office for the United Kingdom in South East Asia, Public Relations Office, Singapore, and the Department of Information, Federation of Malaya, December 1951, hlm. 18.

8 Ibid.

9 Clutterbuck, R., Riot and Revolution In Singapore and Malaya 1945-1963, London: Faber and Faber Limited, 1973, hlm. 188-189.

${ }^{10}$ Antara Undang-undang Darurat yang dilaksanakan oleh pihak kerajaan adalah seperti The Emergency (Criminal Trials) Regulations 1948, The Emergency (Detained Persons) Regulations 1948, The Emergency (Registration Areas) Regulations 1948, dan The Emergency (Auxiliary Police) Regulations 1948. Maklumat lanjut, rujuk Hassan Yusoff, 'Pasukan Polis Di Tanah Melayu Semasa Bermula Kempen Keganasan Komunis Sehingga Pengisytiharan Undang-undang Darurat: 1947-Ogos 1948', dalam Malaysia dari segi Sejarah, hlm. 19; Abdullah Zakaria Ghazali, Ho Hui Ling \& Mahmud Embong, Darurat Di Kelantan 19481960, hlm. 18-19.

${ }^{11}$ Tugas umum pasukan polis adalah seperti membuat sekatan jalan raya, memeriksa kad pengenalan, menyediakan kawalan rapat, membuat rondaan dan sebagainya. Pada tahun 1952, jumlah pasukan polis adalah seramai 161,281 orang, meliputi 31,164 orang polis am, 86,000 orang auxiliary police dan 44,117 orang Special Constabel. Jumlah batalion tentera yang berada di Tanah Melayu pada tahun 1952 pula adalah sebanyak 10 batalion, terdiri daripada 3 batalion Rejimen Melayu, 5 batalion tentera Gurkha dan 2 batalion tentera British. Rujuk Mohd Azzam Mohd Hanif Ghows, The Malayan Emergency Revisited 1948-1960 A Pictoral History, Kuala Lumpur: AMR Holding Sdn. Bhd., 2007, hlm. 193.

${ }^{12}$ Mohd Azzam Mohd Hanif Ghows, The Malayan Emergency Revisited 1948-1960, hlm. 195.

${ }^{13}$ Ibid., hlm. 200. Dengan perkembangan jumlah anggota, unit ini telah dikembangkan kepada Jungle Companies dan seterusnya merintis kepada penubuhan Police Field Force (PFF).

${ }^{14}$ Ibid., hlm. 203.

${ }^{15}$ Ibid., hlm. 204-205. Pasukan AP terdiri daripada dua unit iaitu bandar dan luar bandar.

${ }^{15}$ Abdullah Zakaria Ghazali, Ho Hui Ling \& Mahmud Embong, Darurat Di Kelantan 1948-1960, hlm. 22.

${ }^{17}$ Briggs telah memindahkan lebih kurang 650,000 setinggan ke 600 buah penempatan baru (Kampung Baru) dalam tempoh empat tahun dengan kos sebanyak AS\$44.3 juta. Rujuk Mohd. Reduan Haji Asli, Pemberontakan Bersenjata Komunis, Kuala Lumpur: Dewan Bahasa dan Pustaka, 2008, hlm. 43. 
${ }^{18}$ Abdullah Zakaria Ghazali, Ho Hui Ling \& Mahmud Embong, Darurat Di Kelantan 1948-1960, hlm. 22.

${ }^{19}$ Ibid., hlm. 25.

${ }^{20}$ Home and Kampung Guards, Fail 10/52, dalam Fail Pejabat Daerah Kemaman Siri A. O. E. 1948-1954.

${ }^{21}$ Majalah Sinar Zaman (Bil. 89,96-97 April, November-Disember) 1980; Abdullah Zakaria Ghazali, Ho Hui Ling \& Mahmud Embong, Darurat Di Kelantan 1948-1960, hlm. 24.

${ }^{22}$ Home Guard Booklet, Fail 939/52, dalam Fail Penerangan Kuala Lumpur 19461963, hlm. 1.

${ }^{23}$ Dennis, P. \& Grey, J., Emergency and Confrontation Australian Military Operations in Malaya and Borneo 1950-1966, Australia: Allen \& Unwin Pty Ltd, 1996, hlm. 58.

${ }^{24}$ Majlis Pengkisahan Sejarah Pasukan Home Guard, Anjuran Arkib Negara Malaysia dan Kementerian Kebudayaan, Kesenian dan Warisan Malaysia, hlm. 2.

${ }^{25}$ Ibid.

${ }^{26}$ Senjata yang digunakan oleh kebanyakan anggota Home Guard adalah senapang patah. Namun, bagi unit-unit Home Guard tertentu yang diberi peranan lebih mencabar dan berat, mereka diberikan rifle sebagai senjata utama.

${ }^{27}$ Perak State Home Guard Manual, dalam Fail Pejabat Setiausaha Kerajaan Negeri Perak, hlm. 1; Abdullah Zakaria Ghazali, 'Menangani Pemberontakan Komunis', dalam Abdullah Zakaria Ghazali, Ho Hui Ling \& Mahmud Embong, Darurat Di Kelantan 1948-1960, hlm. 151; Director of Operations, Malaya, Instruction No. 9 , Defence of New Villages-Delegation of Increased Responsibility to Home Guards, Home Guard, Fail 62/52, Bil. 42, dalam Fail Gerakan Sempadan 1946-1960.

${ }^{28}$ Perak State Home Guard Manual, hlm. 1; Abdullah Zakaria Ghazali, 'Menangani Pemberontakan Komunis', dalam Abdullah Zakaria Ghazali, Ho Hui Ling \& Mahmud Embong, Darurat Di Kelantan 1948-1960, hlm. 151; Director of Operations, Malaya, Instruction No. 9, Defence of New Villages-Delegation of Increased Responsibility to Home Guards, Home Guard, Fail 62/52, Bil. 42, dalam Fail Gerakan Sempadan 1946-1960.

${ }^{29}$ Perak State Home Guard Manual, hlm. 1.

${ }^{30}$ Perak State Home Guard Manual, hlm. 1; Abdullah Zakaria Ghazali, Menangani Ancaman Komunis, dalam Abdullah Zakaria Ghazali, Ho Hui Ling \& Mahmud Embong, Darurat Di Kelantan 1948-1960, hlm. 151.

${ }^{31}$ Perak State Home Guard Manual, hlm. 1; Abdullah Zakaria Ghazali, 'Menangani Ancaman Komunis', dalam Abdullah Zakaria Ghazali, Ho Hui Ling \& Mahmud Embong, Darurat Di Kelantan 1948-1960, Kota Bharu: Perbadanan Muzium Negeri Kelantan, 2009, hlm. 151.

${ }^{32}$ Perak State Home Guard Manual, hlm. 1.

${ }^{33}$ Ibid. Min Yuen pada awal Darurat berperanan membekalkan sumber bekalan keperluan, maklumat risikan, dan anggota baru untuk tujuan peperangan. Namun demikian, apabila PKM mula ditekan oleh pasukan keselamatan, anggota Min Yuen ini turut terlibat dalam pertempuran bersenjata dengan pasukan keselamatan. Anggota Min Yuen ini biasanya aktif bergerak di kawasan penempatan semula orang Cina yang berdekatan dengan kawasan hutan simpan, penempatan Melayu, dan lombong serta estet milik persendirian. Sila rujuk, 
Andaya, Barbara Watson dan Leonard Y, A History of Malaysia, Second Edition, Houndmills: Palgrave Publishers Ltd., 2001, hlm. 271.

${ }^{34}$ Perak State Home Guard Manual, hlm. 6.

${ }^{35}$ Home Guard Booklet, hlm. 1.

${ }^{36}$ Majlis Pengkisahan Sejarah Pasukan Home Guard, hlm. 3.

${ }^{37}$ Ibid., hlm. 4.

${ }^{38}$ Ibid.

${ }^{39}$ Majlis Pengkisahan Sejarah Pasukan Home Guard, hlm. 4.

${ }^{40}$ Ibid.; Abdullah Zakaria Ghazali, Ho Hui Ling \& Mahmud Embong, Darurat Di Kelantan 1948-1960, hlm. 26.

${ }^{41}$ Majlis Pengkisahan Sejarah Pasukan Home Guard, hlm. 4.. Di awal penubuhan pasukan Home Guard, terdapat masalah yang timbul di mana senjata yang dibekalkan oleh pihak kerajaan telah diberikan kepada pihak komunis. Hal ini demikian kerana terdapat mereka yang menjadi ahli pasukan Home Guard merupakan mereka yang menyokong, bersimpati, atau takut dengan ancaman pihak komunis. Inilah risiko yang terpaksa dihadapi oleh Sir Gerald Templer apabila pada penghujung tahun 1953 pasukan Home Guard dibekalkan dengan senjata yang lengkap. Namun demikian, proses ini menghadapi masalah kerana jumlah senjata yang tidak mencukupi. Rujuk Abdullah Zakaria Ghazali, Ho Hui Ling \& Mahmud Embong, Darurat Di Kelantan 1948-1960, hlm. 26.

${ }^{42}$ Arms and Ammunition from Home Guards: Seizure of., Home Guard in Sungai Siput Area, Fail 58/51, Bil. 35, dalam Fail Pejabat Daerah Sungai Siput Perak 1949-1960.

43 Ibid.

${ }^{44}$ Perak State Home Guard Manual, hlm. 6.

${ }^{45}$ Ho Hui Ling, Darurat 1948-1960, hlm. 19; Abdullah Zakaria Ghazali, Ho Hui Ling \& Mahmud Embong, Darurat Di Kelantan 1948-1960, hlm. 25.

${ }^{46}$ Majlis Pengkisahan Sejarah Pasukan Home Guard, hlm. 3.

${ }^{47}$ Ho Hui Ling, Darurat 1948-1960, hlm. 19; Abdullah Zakaria Ghazali, Ho Hui Ling \& Mahmud Embong, Darurat Di Kelantan 1948-1960, hlm. 25.

48 Perak State Home Guard Manual, hlm. 9.

${ }^{49}$ Ibid.,hlm. 3.

${ }^{50}$ Ibid.

${ }^{51}$ Ibid.

${ }^{52}$ Ibid., hlm. 4.

53 Ibid.

${ }^{54}$ Ibid.

${ }^{55}$ Home Guard Booklet, hlm. 2.

${ }^{56}$ Ibid.

${ }^{57}$ Ibid.

${ }^{58}$ Ibid.

59 Ibid.

60) Home Guard Miscellaneous, Fail KLTN STATE SECT 3005/1955, dalam Fail Pejabat Setiausaha Kerajaan Negeri Kelantan.

61 Ibid. 
${ }^{62}$ Ho Hui Ling, Darurat 1948-1960, hlm. 19-21. Di awal penubuhannya, Majlis Perang Persekutuan dipenerusikan oleh Pengarah Operasi dan dianggotai Ketua Setiausaha, Setiausaha Pertahanan, Panglima Angkatan Tentera, dan Ketua Polis Negara. Kemudian majlis ini ditambah keanggotaannya dengan dua orang wakil orang Melayu, seorang wakil orang Cina, dan seorang mewakili peladang Eropah manakala Pesuruhjaya Tinggi bertindak sebagai Pengerusi Majlis Persekutuan. Rujuk Mohd. Reduan Haji Asli, Pemberontakan Bersenjata Komunis, hlm. 50-51; Abdullah Zakaria Ghazali, Ho Hui Ling \& Mahmud Embong (Eds.), Darurat Di Kelantan 1948-1960, hlm. 27.

${ }^{63}$ Ho Hui Ling, Darurat 1948-1960, hlm. 21. SWEC dipengerusikan oleh Menteri Besar atau Penasihat British di negeri-negeri Melayu dan Suruhanjaya Residen (Resident Commission) di Negeri-negeri Selat, dan dianggotai oleh Ketua-ketua Polis Negeri dan Ketua-ketua Tentera Tempatan. Rujuk Mohd. Reduan Haji Asli, Pemberontakan Bersenjata Komunis, hlm. 51; Abdullah Zakaria Ghazali, Ho Hui Ling \& Mahmud Embong (Eds.), Darurat Di Kelantan 1948-1960, hlm. 27.

${ }^{64}$ Ho Hui Ling, Darurat 1948-1960, hlm. 21. DWEC dipengerusikan oleh Pegawai Daerah. Majlis ini dianggotai oleh Ketua Polis Daerah, Ketua Cawangan Khas (KCK) dan Pegawai Tentera Tempatan. Rujuk Mohd. Reduan Haji Asli, Pemberontakan Bersenjata Komunis, hlm. 51; Abdullah Zakaria Ghazali, Ho Hui Ling \& Mahmud Embong (Eds.), Darurat Di Kelantan 1948-1960, hlm. 28.

${ }^{65}$ R. Clutterbuck, The Long Long War, hlm. 58.

${ }^{66}$ Home Guard, Fail 106/52, dalam Fail Gerakan Sempadan 1946-1960.

${ }^{67}$ Tbid.

${ }^{68}$ Ibid.

${ }^{69}$ Home Guard, Fail 58/51/51, dalam Fail Pejabat Daerah Sungai Siput Perak 19491969.

${ }^{70}$ Ibid.

${ }^{71}$ Ibid.

${ }^{72}$ Ibid.; Mohd. Reduan Haji Asli, Pemberontakan Bersenjata Komunis, hlm. 52.

${ }^{73}$ Home Guards ( Amalgamation of Home Guards, Kampong Guards and Auxiliary Police), Fail B. A. 130/1953, dalam Fail British Adviser's Office, Selangor.

${ }^{74}$ R. Clutterbuck, The Long Long War, hlm. 59.

${ }^{75}$ Home Guard Organisation in Klian Intan, Upper Perak, Fail DHG Kroh 18/52, dalam Fail Pejabat Daerah/Tanah Kroh, Perak 1942-1967.

${ }^{76}$ Ibid.

${ }^{77}$ Majlis Pengkisahan Sejarah Pasukan Home Guard, hlm. 5.

${ }^{78}$ Ibid.

${ }^{79}$ Ibid.

${ }^{80}$ Ho Hui Ling, Darurat 1948-1960, hlm. 136.

${ }^{81}$ Pesuruhjaya Tinggi British di Tanah Melayu, Sir Henry Gurney telah terkorban dalam serangan hendap yang dilakukan oleh pengganas komunis sewaktu beliau dalam perjalanan ke Bukit Fraser pada 7 Oktober 1952. Raj (JR), J.J., The Struggle For Malaysian Independence, hlm. 114; Stewart, B., Smashing Terrorism in the Malayan Emergency The Vital Contribution of the Police, Subang Jaya: Pelanduk Publications (M) Sdn Bhd, 2004, hlm. 175.

${ }^{82}$ Majlis Pengkisahan Sejarah Pasukan Home Guard, hlm. 3. 
${ }^{83}$ Ibid.

${ }^{84}$ Ibid.

${ }^{85}$ Ibid.

${ }^{86}$ Sehingga November 1951, pasukan Home Guard terdiri daripada 806 unit. Unitunit ini termasuklah 16 unit di Pahang dengan 3,313 orang anggota; 81 unit di Kelantan dengan 1,760 orang anggota; 31 unit di Melaka dengan 1,005 orang anggota; 25 unit di Selangor dengan 6,488 orang anggota; 36 unit di Negeri Sembilan dengan 1,361 orang anggota; 429 unit di Johor dengan 41,811 orang anggota. Maklumat lanjut, rujuk Abdullah Zakaria Ghazali, Ho Hui Ling \& Mahmud Embong, Darurat Di Kelantan 1948-1960, hlm. 26; Home Guard, Kuala Lumpur, 12 November 1951, dalam Fail Pejabat Daerah Kemaman A.O.E., Terengganu, A.O.E. 10/52, Home and Kampong Guards; Majlis Pengkisahan Home Guard, hlm. 3.

${ }^{87}$ Majlis Pengkisahan Home Guard, hlm. 3.

${ }^{88}$ Ho Hui Ling, Darurat 1948-1960, hlm. 150.

${ }^{89}$ Ibid.

${ }^{90}$ Ibid.

${ }^{91}$ Sinar Zaman, hlm. 30.

${ }_{92}$ Ibid.

${ }^{93}$ Ibid.

${ }^{94}$ Home Guard-Confidential Miscellaneous, Fail Klntn Wec. Conf. 306/1957.

95 Ibid.

96 Ibid.

97 Ibid.

98 Ibid.

99 Ibid.

${ }^{100}$ Ibid.

${ }^{101}$ Sinar Zaman, hlm. 31.

${ }^{102}$ R. Clutterbuck, The Long Long War, hlm. 81-82.

${ }^{103}$ Ibid., hlm. 82.

${ }^{104}$ Ibid.

${ }^{105}$ Home Guard-Confidential Miscellaneous, Fail Kltn Wec. 306/1957.

${ }^{106}$ Ibid.

${ }^{107}$ Mohd. Reduan Haji Asli, Pemberontakan Bersenjata Komunis, hlm. 60.

${ }^{108}$ Home Guard Honours and Awards, Fail 832/52, dalam Fail Daerah Larut dan Matang 1945-1952. 